\title{
Seasonal Changes in Nonstructural Carbohydrates in Cranberry
}

\author{
Marianna Hagidimitriou ${ }^{1}$ and Teryl R. Roper ${ }^{2}$ \\ Department of Horticulture, University of Wisconsin-Madison, Madison, WI 53706
}

Additional index words. Vaccinium macrocarpon, carbon partitioning, soluble sugars, starch, fruit set

\begin{abstract}
Searles' (low yielding) and 'Stevens' (high yielding) cranberry (Vaccinium macrocarpon Ait.) tissues were collected in 1990 and 1991 to determine the concentration of nonstructural carbohydrates in above-ground (uprights, woody stems) and below-ground tissue. Uprights had the highest total nonstructural carbohydrate (TNC) concentration, followed by woody stems, while below-ground tissue contained the lowest TNC concentration. Total nonstructural carbohydrate concentration in uprights increased early in the season, reached a maximum in late May, decreased as flowering approached, and remained low from late June to late August. The latter period corresponds to flowering, fruit set, floral initiation, and fruit development stages. In late August, when fruit were full size, TNC levels increased, reaching highest concentration in November as the plants were entering dormancy. Most TNC increase in the early season and the subsequent decrease were due to changes in starch. The increase of TNC late in the season was primarily due to increases in soluble carbohydrates. Total nonstructural carbohydrate concentration was greater in vegetative than fruiting uprights for the entire growing season. The lower TNC concentration in fruiting than vegetative uprights during flowering and fruit set was due to greater starch depletion in fruiting uprights. Seasonal changes in TNC in the two cultivars were similar; however, 'Stevens' had generally higher TNC concentration and total dry weight as well as more fruiting uprights, fruit, and fruit weight per ground area. The low TNC concentration observed during fruit set and development suggests that the demands for carbohydrates are highest during that period and supports the hypothesis that competition for carbohydrate resources is one factor responsible for low cranberry fruit set.
\end{abstract}

The American cranberry, indigenous to North America, is an evergreen, woody, perennial creeping vine. The vines, called runners, can reach a length of $2 \mathrm{~m}$ and spread over the soil surface to form a mat (Eck, 1990). Vertical branches, called uprights, originate from the vines. Uprights terminate with a vegetative or mixed bud. Flowers and fruit are borne laterally on the new shoot growth. In Wisconsin, visible bud growth in cranberry occurs in mid-May with shoot elongation, and some leaf expansion occurs before flowering. Flowering begins in late June and continues for 3 to 4 weeks into July. The flowers on an individual upright undergo anthesis acropetally. Floral induction occurs soon after flowering with continuous differentiation of flower parts during the remainder of the summer and in the spring of the following year (Dana, 1990). The fruit matures 60 to 120 days or more after fertilization depending on cultivar characteristics and weather. Harvest begins in late September and continues through October.

Eaton and Kyte (1978) have shown that the number of fruiting uprights per unit of ground area and fruit set are the two primary factors important in determining cranberry yield. A cranberry field produces an abundance of flowers but only $30 \%$ to $40 \%$ of the flowers set fruit (Bain, 1946; Bergman, 1950). Marucci (1966) proposed that limited fruit set in cranberry flowers is due to insufficient energy resources to allow a fruit to develop from every flower.

Bauman and Eaton (1986) concluded that competition occurs between berries on a cranberry upright, with earlier opening flowers in lower positions being more likely to develop into fruit, apparently suppressing set in the remaining upper flowers. Removal of the lower two flowers on cranberry uprights allowed $45 \%$ to $58 \%$ of the remaining flowers to develop fruit, while with fruit

Received for publication 29 July 1993. Accepted for publication 15 Dec. 1993. This research was supported in part with funds from Ocean Spray Cranberries and the Wisconsin Cranberry Board. The cost of publishing this paper was defrayed in part by the payment of page charges. Under postal regulations, this paper therefore must be hereby marked advertisment solely to indicate this fact.

${ }^{1}$ Graduate research assistant.

${ }^{2}$ Assistant professor. present in the lower position only $17 \%$ to $19 \%$ of the remaining upper flowers set and developed fruit (Birrenkott and Stang, 1990). Removing new vegetative growth acropetal to flowers or fruit reduced fruit set most in mid-July, during the fruit set period. Carbohydrate concentration in cranberry uprights is lowest as early flowers set and upper flowers are at or just beyond anthesis, suggesting that developing fruits compete for available carbohydrates (Birrenkott et al., 1991).

Carbohydrate partitioning data in cranberry are limited. A recent study in cranberry has shown changes in carbohydrate concentration in current season and previous season uprights and woody stems (Birrenkott et al., 1991). Little is known about the relative contribution of carbohydrates from above-ground vs. below-ground cranberry tissue or carbohydrates from reserves vs. current season assimilates. Information on carbohydrate allocation in fruiting vs. vegetative uprights is also not available.

Cultivars of the same species may differ significantly in yield. Borras et al. (1984) found relationships between yield and carbohydrate concentrations in vegetative structures of two cultivars of sweet orange.

This research was initiated to a) investigate the distribution pattern of nonstructural carbohydrates between above-ground tissue (uprights, woody stems) and below-ground tissue (roots, below-ground woody stems) during the growing season under field conditions, b) determine the differences in carbohydrate concentration between fruiting and vegetative uprights, and c) relate carbohydrate concentration in a high-yielding (Stevens) and a lower-yielding (Searles) cultivar to fruit set and yield.

\section{Materials and Methods}

Plant material. Samples for carbohydrate analysis were collected in 1990 and 1991 from beds of 'Searles' and 'Stevens' cranberry at DuBay Cranberry Company, near Stevens Point, Wis. During 1990, samples were taken every 3 weeks throughout the growing season. Samples were also collected every 3 weeks during 1991, except for weekly sampling during bloom and fruit set. 
Samples were not collected during winter months because vines were covered with $30 \mathrm{~cm}$ of ice. Each cranberry bed was separated into six segments and six samples of cranberry plants and soil were taken from the six different locations in the bed. Samples were taken using a probe $\left(15 \mathrm{~cm}\right.$ in diameter) that removed $126 \mathrm{~cm}^{2}$ of land surface area. The plugs of cranberry vines and soil were placed on ice, brought into the laboratory, and separated into uprights with fruit (fruiting uprights), uprights without fruit (vegetative uprights), woody stems, below-ground tissue, and fruit (when applicable). Fruiting and vegetative uprights included current season and previous season parts of the uprights, while belowground tissue included the fine cranberry roots and below-ground woody stems. Soil and debris were washed from the below-ground tissue. Plant materials were dried in a forced-air oven at $55 \mathrm{C}$, then ground to 40 mesh in a Wiley mill. This procedure was found to produce the same results as when tissues were lyophilized.

Carbohydrate analysis. Soluble carbohydrates were analyzed by high-performance liquid chromatography (HPLC) similar to the procedure of McBee and Maness (1983). Carbohydrates were extracted from 100-mg subsamples with $5 \mathrm{ml} 80 \%$ ethanol and 3 $\mathrm{mg}$ mannitol as internal standard, incubated at $55 \mathrm{C}$ for $1 \mathrm{~h}$, then vacuum filtered, and the solids were saved for starch analysis. The filtrate $\mathrm{pH}$ was adjusted to 7 with $0.2 \mathrm{M} \mathrm{KOH}, 400 \mathrm{mg}$ anionexchange resin (Biorex 5, 200-400 mesh, chloride form, Bio-Rad, Richmond, Calif.) was added, and samples were shaken for $30 \mathrm{~min}$. The resin was filtered out and the filtrates were dried at $55 \mathrm{C}$. The samples were resuspended in $3 \mathrm{ml}$ deionized-degassed water and filtered through a $0.45-\mu \mathrm{m}$ filter, and a $200-\mu \mathrm{l}$ aliquot was injected into an isocratic HPLC (model 110B; Beckman, San Ramon, Calif.). A Beckman $\mu$-Spherogel carbohydrate column (7.5-mm Ca-based resin) and a refractive index detector (Knauer, Hamburg, Germany) were used for soluble carbohydrate separation and detection, respectively. Peak areas were determined with an integrator (model 3394A; Hewlett Packard, Avondale, Pa.).

Starch assay. The dried solids from the first filtration were resuspended in $2 \mathrm{ml} 0.1 \mathrm{M}$ acetate buffer ( $\mathrm{pH} \mathrm{5)}$ and autoclaved at 250C for $30 \mathrm{~min}$. After the samples were cooled, 23 units amyloglucosidase (Sigma, St Louis) were added, vortexed, and incubated in a shaking water bath for $16 \mathrm{~h}$ at $55 \mathrm{C}$. The resulting glucose was quantified colorimetrically using a glucose oxidase assay (Sigma).

The experimental design is repeated measures over dates, blocking the bed into six segments. At each date, the design was randomized complete block for the comparison of tissues. Repeated measures analysis, using general linear models in SAS (SAS Institute, 1987), found significant tissue by date interactions with no consistent pattern by dates. Thus, results reported below are based on separate analysis by date. Mean separation was done by LSD following a significant $\mathrm{F}$ test.

Ten additional samples of cranberry uprights were taken from the same beds of 'Searles' and 'Stevens' in 1991 and 1992. In each location ten rings $\left(81 \mathrm{~cm}^{2}\right)$ were placed at 1-m intervals along a 10$m$ transect and were inserted into the canopy using a support stake. At the end of each growing season, before the commercial harvest, all uprights in the rings were collected. For each sample, total number of fruiting uprights, vegetative uprights, flowers, and fruit was counted and percent fruit set was calculated. Fruit from each sample were also weighed. Data were analyzed by $t$ test.

\section{Results}

Total nonstructural carbohydrates (TNCs) of cranberry tissues were composed of starch, sucrose, glucose, and fructose. Total nonstructural carbohydrates were measured as milligrams of carbohydrates per $100 \mathrm{mg}$ tissue dry weight; thus, it is expressed as a percentage of the total dry weight.

The results in 1990 and 1991 were similar; thus, only the 1991 season results are presented here. Seasonal TNC concentration varied the most in uprights (Fig. 1). In May, before new shoot expansion, TNC levels began to increase in uprights of both 'Stevens' and 'Searles', reaching a maximum in late May. 'Stevens' uprights contained a maximum of $12 \%$ TNC and 'Searles' uprights $10 \%$ TNC. Total nonstructural carbohydrates declined in both cultivars, beginning before bloom. Total nonstructural carbohydrate levels declined to $7.7 \%$ and $6.2 \%$ for 'Stevens' and 'Searles', respectively, at the beginning of flowering in late June. Total nonstructural carbohydrate concentration remained low from late June to late August when flowers are initiated for the following season and current fruit grow and develop. In late August, when fruit have reached full size, TNC concentration began to increase, reaching the highest concentration in November as plants became dormant. Total nonstructural carbohydrate concentration was significantly higher in the early season (May) than in the midseason (late June to late August). Total nonstructural carbohydrate concentration was also higher in the late season (September to November) than midseason, verified with statistical analysis.

The pattern of change in TNC concentration in woody stems during the season reflected that of uprights, but was less marked (Fig. 1). 'Stevens' woody stems contained about 6\% TNCs and 'Searles' about 3\% TNCs during the season. Stem TNC levels increased late in the season, as the plants were entering dormancy

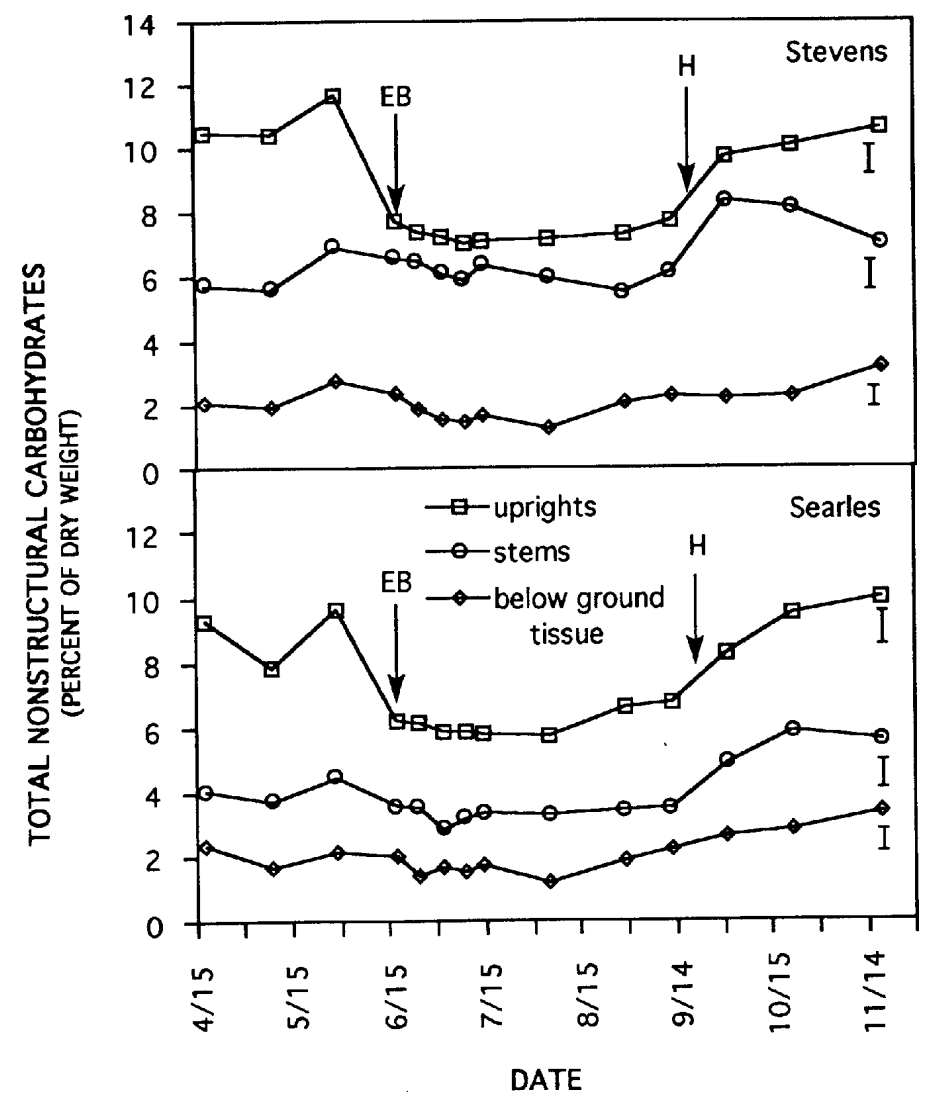

Fig. 1. Seasonal changes in total nonstructural carbohydrates (TNCs) (percent of total dry weight) in different tissue of cranberry vines during 1991. TNCs among uprights, stems, and roots were significantly different at each measurement $(P \leq$ $0.05)$. $\mathrm{EB}=$ early bloom, $\mathrm{H}=$ harvest; $\mathrm{n}=6$. 


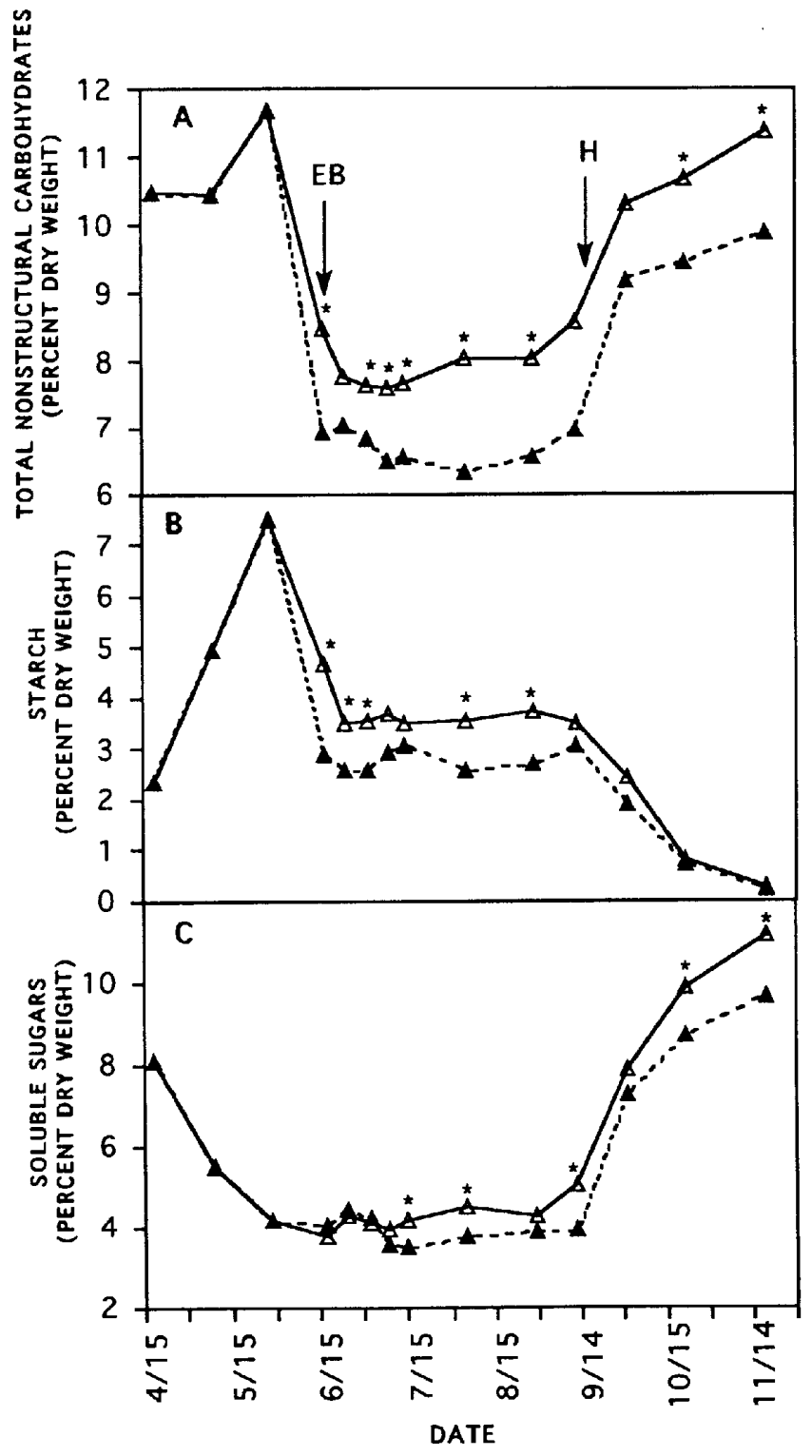

Fig. 2. Total nonstructural carbohydrates (TNCs) (A), starch (B), and soluble sugars $(\mathbf{C})$ in vegetative and fruiting uprights of 'Stevens' cranberry vines during 1991. TNC, starch, and soluble sugar concentrations were significantly higher at $P \leq 0.05$ in vegetative than fruiting uprights at sampling dates marked with an asterisk. $\mathrm{EB}=$ early bloom, $\mathrm{H}=$ harvest; $\mathrm{n}=6 ; \Delta=$ vegetative uprights, $\boldsymbol{\Delta}=$ fruiting uprights.

in both cultivars. Below-ground tissue had the lowest TNC concentration, $2 \%$ of total dry weight, and remained stable throughout the season with an increase occurring only late in the season. Total nonstructural carbohydrate concentrations among uprights, stems, and below-ground tissue were significantly different on all sampling dates, for each year and cultivar, with uprights always having the highest, and below-ground tissue the lowest, TNC concentration.

Most of the increase of TNC in uprights early in the season was due to increases in starch. Starch concentration increased sharply early in the season in both cultivars, reaching a maximum of $8 \%$ in 'Stevens' (Fig. 2B) and 5\% in 'Searles' (Fig. 3B), respectively. Starch concentration then decreased in both cultivars, reaching a minimum in November. Starch made up the largest fraction of the upright TNC in 'Stevens' and 'Searles' (65\% and 55\% of TNCs, respectively) at the early season peak. The increase of TNCs late

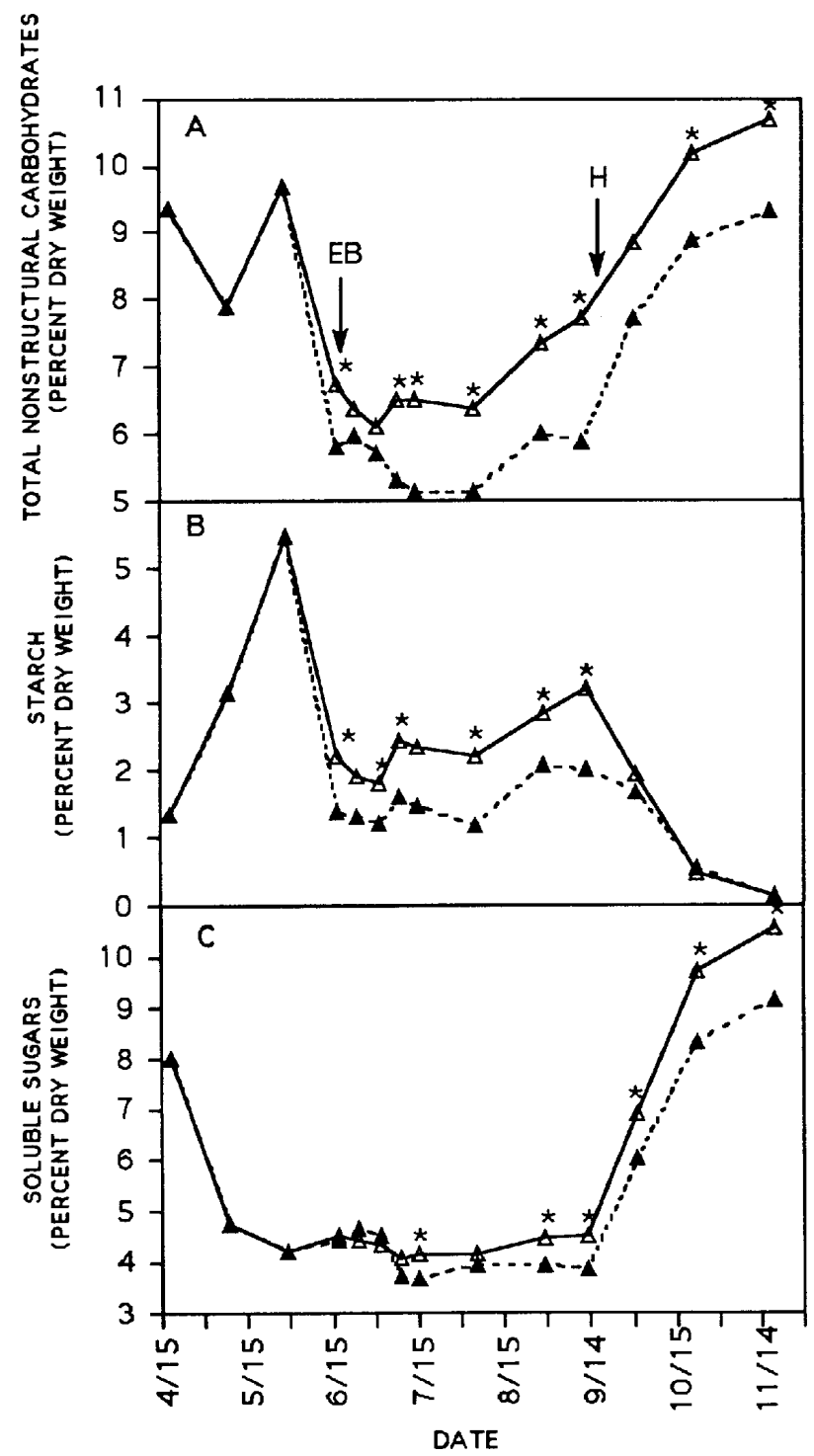

Fig. 3. Total nonstructural carbohydrates (TNCs) (A), starch (B), and soluble sugars $(\mathbf{C})$ in vegetative and fruiting uprights of 'Searles' cranberry vines during 1991. TNC, starch, and soluble sugar concentrations were significantly higher at $P \leq 0.05$ in vegetative than fruiting uprights at sampling dates marked with an asterisk. $\mathrm{EB}=$ early bloom, $\mathrm{H}=$ harvest; $\mathrm{n}=6 ; \Delta=$ vegetative uprights, $\boldsymbol{\Delta}=$ fruiting uprights.

in the season was primarily due to increases in soluble carbohydrates. Soluble carbohydrates decreased early in the season, remained almost stable through midseason, and increased again late in the season. The changes in soluble carbohydrate concentration early and late in the season was mostly due to changes in sucrose (data not shown).

Total nonstructural carbohydrate concentration was generally greater in vegetative uprights than fruiting uprights (Figs. 2A and $3 \mathrm{~A})$. The differences in TNC between fruiting and vegetative uprights during the flowering and fruit set period were due to greater starch depletion in flowering uprights (Figs. 2B and 3B). Late in the season, there were significant differences in TNC between fruiting and vegetative uprights due to higher soluble sugar accumulation in vegetative uprights (Figs. 2C and 3C).

Seasonal changes in TNC in fruits were similar in both cultivars in both years (data not shown). Total nonstructural carbohydrate concentration increased throughout fruit development, reaching maximum at harvest. At that stage, TNC concentration was $27 \%$ 


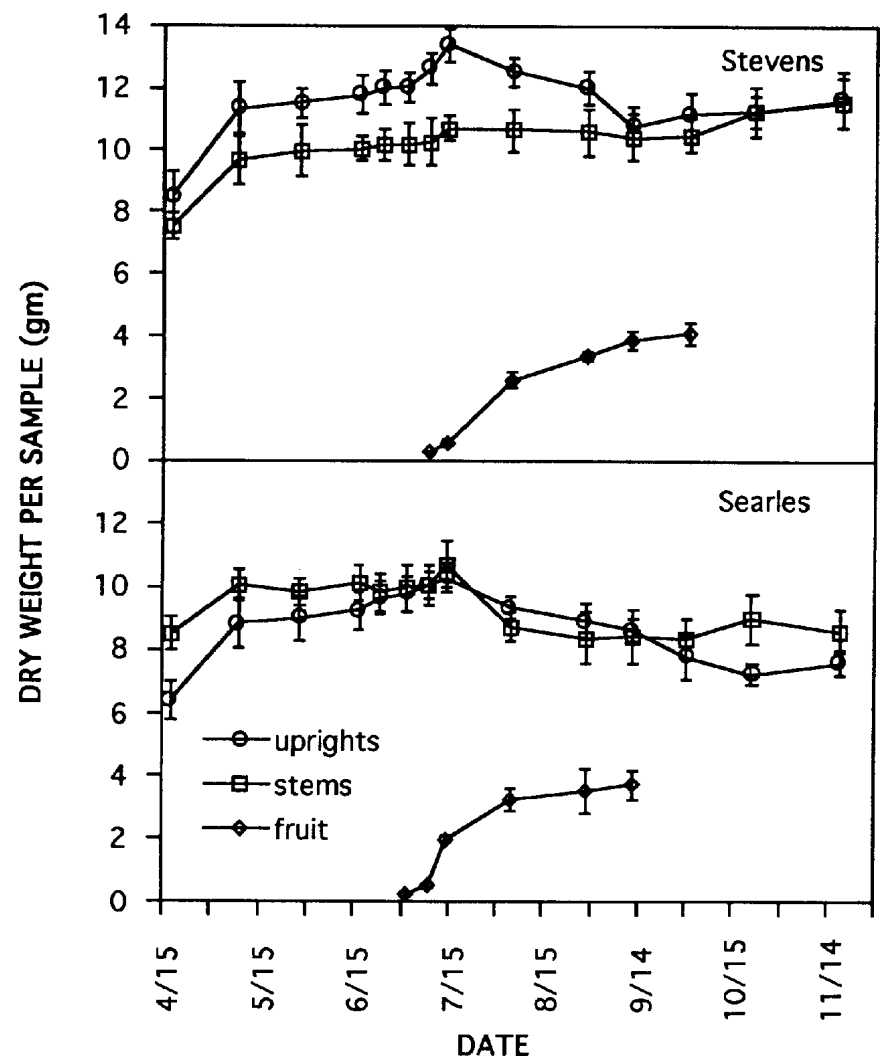

Fig. 4. Seasonal changes in dry weight of cranberry uprights, stems, and fruit in 1991. Each point represents a mean of six measurements.

and $29 \%$ in 'Stevens' and 'Searles', respectively, for 1991. Glucose made up $80 \%$ of TNC, fructose $16 \%$, and sucrose $4 \%$. Starch was not detected in the fruit. 'Stevens' had generally higher TNC than 'Searles' in all tissue both years. There were no significant interactions between years and cultivars $(P \leq 0.05)$.

In 'Stevens', about $16 \%$ of total dry weight was uprights, $13 \%$ woody stems, $4 \%$ fruit, and $67 \%$ below-ground tissue. In 'Searles', $\approx 16 \%$ was uprights, $18 \%$ woody stems, $3 \%$ fruit, and $63 \%$ belowground tissue.

'Stevens' always had higher dry weight than 'Searles' both in above-ground (Fig. 4) and below-ground tissue (data not shown). Dry weight in uprights and woody stems increased from May through the end of July. There was a decrease in upright and woody stem dry weight during August and September, with a slight increase occurring again late in the season as reserves accumulated (Fig. 1). Fruit dry-weight increase was rapid in July and August while the growth rate slowed in September.

Even though seasonal changes in TNC in the two cultivars were similar, 'Stevens' generally had higher TNC concentration and greater dry weight than 'Searles'. Fruit set (expressed as percentage) was higher in 'Stevens' than 'Searles' only in 1992. However, the number of fruiting uprights, fruit number per ring, fruit number per upright, mean fruit weight, and yield was higher in 'Stevens' than 'Searles' both years (Table 1).

\section{Discussion}

Concentration and seasonal changes in TNC in cranberry depended on the tissue type. The higher TNC concentration and the more dramatic seasonal changes in uprights than in woody stems suggest that uprights are most important in supporting flowering, fruit set, and fruit development, while the contribution of belowground tissue was least important.

The increase in TNC concentration in uprights early in the season was primarily due to accumulation of starch rather than soluble sugars (Figs. 2 and 3). Most of the starch accumulated during spring is probably derived from currently fixed photoassimilates. In May, before new upright expansion, 1-yearold cranberry leaves are photosynthetically competent (Hagidimitriou, 1993). One-year-old leaves can assimilate C early in the season, which is likely stored as starch. Thus, $\mathrm{C}$ assimilation appears to exceed carbohydrate consumption early in the season as shown by the early accumulation of starch.

As upright growth began, TNC concentration in uprights began to decrease due primarily to a decrease in starch, reaching a minimum during fruit set and development. The new expanding uprights apparently are the main sinks for carbohydrates before flowering while during fruit set developing fruitlets become strong sinks (Hawker and Stang, 1985). The observed decrease cannot be due to dilution in carbohydrate concentration as plant volume increases, since the increase in upright dry weight at that time is not as sharp as the decrease in starch concentration (Fig. 4). Hawker and Stang (1985) also reported that upright growth terminates by the end of July, while a dry-weight increase was noted near the end of the season. The changes observed in starch concentration early in the season suggest that starch is stored in uprights and woody stems and is then mobilized to growing points during periods of high demands. The increase in TNC concentration late in the season was due almost entirely to an increase in soluble sugars, predominantly sucrose. Starch is the main nonstructural carbohydrate during early growth and is present both in leaves and woody stems (data not shown), whereas soluble sugars, mostly sucrose, predominate in early fall and during dormancy. The increase in soluble sugars has been associated with low temperatures and cold hardiness during dormancy (Sieckman and Boe, 1978).

This pattern of spring reserve increase, as starch, and subsequent depletion with replacement later in the season has been observed in other evergreen species. In Vaccinium vitis-idaea, carbohydrate concentration increases during the spring until shoot elongation begins, with the increase mostly as starch (Bannister, 1980; Fonda and Bliss, 1966; Stewart and Bannister, 1973). When fruit are present a large portion of the carbohydrate reserves is consumed, but by the end of the season carbohydrate levels increase to levels similar to spring. The same pattern is observed in Pinus species (Little, 1970). Most of the starch accumulating in conifers during spring was synthesized from current photosynthesis. Karlsson (1985) similarly concluded for Vaccinium vitis-idaea that new shoot growth is mainly dependent on early summer assimilates produced by old leaves.

The pattern of carbohydrate changes for cranberry agrees in general with the results of Birrenkott et al. (1991) except for the noticeable springtime increase and subsequent decrease in starch level we found with our earlier and more frequent sampling. They found that 'Stevens' cranberry uprights have lowest carbohydrate concentration at late blossom. Carbohydrate levels then increase as fruit growth slows and are highest at dormancy. However, they reported that stachyose and raffinose were present in cranberry uprights during dormancy. We did not detect stachyose or raffinose, in agreement with Sieckman and Boe (1978). Birrenkott et al. (1991) also reported higher soluble sugar levels in uprights during dormancy ( $25 \%$ on a dry-weight basis) while we found that soluble sugars increase to levels similar to those during spring (12\% on a dry-weight basis).

The observed sharper decrease and lower TNC concentration in 
Table 1. Average yield and fruit set in 'Stevens' and 'Searles' cultivars for 2 years.

\begin{tabular}{|c|c|c|c|c|c|c|c|c|}
\hline Year & Cultivar & $\begin{array}{c}\text { Wisconsin } \\
\text { mean yield } \\
\text { per acre }{ }^{\mathrm{z}} \\
(\mathrm{Mt} / \mathrm{ha})\end{array}$ & $\begin{array}{c}\text { No. of } \\
\text { fruiting } \\
\text { uprights } \\
\left(\text { per } 81 \mathrm{~cm}^{2} \text { ) }\right.\end{array}$ & $\begin{array}{c}\text { No. of } \\
\text { vegetative } \\
\text { uprights } \\
\left(\text { per } 81 \mathrm{~cm}^{2}\right)\end{array}$ & $\begin{array}{c}\text { Fruit } \\
\text { no. } \\
\left(\operatorname{per} 81 \mathrm{~cm}^{2}\right)\end{array}$ & $\begin{array}{l}\text { Fruit } \\
\text { no. per } \\
\text { upright }\end{array}$ & $\begin{array}{c}\text { Fruit } \\
\text { set } \\
(\%)\end{array}$ & $\begin{array}{c}\text { Total } \\
\text { fruit } \\
\text { weight } \\
\left(\mathrm{g} / 81 \mathrm{~cm}^{2}\right)\end{array}$ \\
\hline \multirow[t]{3}{*}{1991} & Stevens & 12.7 & 16.2 & 25.5 & 13.0 & 0.80 & 23 & 16.7 \\
\hline & Searles & 7.3 & 11.6 & 27.7 & 6.9 & 0.59 & 20 & 9.5 \\
\hline & Significance & & $*$ & NS & $*$ & $*$ & NS & $*$ \\
\hline \multirow[t]{3}{*}{1992} & Stevens & 17.5 & 18.2 & 36.1 & 21.3 & 1.17 & 37 & 25.4 \\
\hline & Searles & 13.0 & 15.3 & 40.7 & 13.4 & 0.87 & 25 & 18.6 \\
\hline & Significance & & $*$ & NS & $*$ & $*$ & $*$ & $*$ \\
\hline
\end{tabular}

${ }^{\mathrm{Z}}$ Data from Ocean Spray Cranberries.

Ns, ${ }^{*}$ Nonsignificant or significant at $P=0.05$. Data analyzed by $t$ test.

fruiting uprights than in vegetative uprights during flowering reflected lower starch concentration. Starch apparently is mobilized within uprights to support vegetative and reproductive growth. The decrease in TNC in vegetative uprights could represent carbohydrate export to nearby fruiting uprights or the demand for carbohydrates to support vegetative growth. The greater decrease in TNC in fruiting than vegetative uprights and the lower TNC concentration during the fruit development period suggests that a large portion of carbohydrates needed for fruit growth comes first from the nearest source, which is the upright on which the fruit are borne.

The low carbohydrate levels observed in this study during flowering and fruit set are consistent with the hypothesis that insufficient energy resources are available for development of a fruit from every flower (Bauman and Eaton, 1986; Marucci, 1966). Competition between vegetative and reproductive sinks for resources might also be a factor affecting fruit set since upright growth and low carbohydrate concentrations in uprights continue through July (Figs. 1 and 4).

Overall, 'Stevens' had higher TNC concentration as well as higher yield than 'Searles', the result of increased number of fruiting uprights and the number of fruit per upright (Table 1), suggesting a relationship between carbohydrate levels and yield in cranberry.

Competition for resources may extend beyond carbohydrates to other essential substances, such as $\mathrm{N}$ and other nutrients. Nitrogen concentration in cranberry uprights decreased during flowering (Hagidimitriou, 1993). Limitation in the supply of mineral elements might affect fruit set and development in cranberry as well. Hormonal involvement in cranberry fruit set and development cannot be ruled out, either.

The consistently lower concentrations of TNC in fruiting uprights compared to nonfruiting uprights and the low TNC concentrations at fruit set suggest that carbohydrate availability is a primary limitation of fruit set in cranberry. Management strategies for cranberry need to be developed that will maximize TNC concentrations at and before flowering and fruit set. Breeding and selection of new cultivars may also benefit from examining TNC concentrations at critical times.

\section{Literature Cited}

Bain, H.F. 1946. Blooming and fruiting habits of the cranberry in Wisconsin. Cranberries 10:11-14.

Bannister, P. 1980. The nonstructural carbohydrate contents of ericaceous shrubs from Scotland and Austria. Acta Oecologia/Oecol. Plant.
1(15):275-292.

Baumann, T.F. and G.W. Eaton. 1986. Competition among berries on the cranberry upright. J. Amer. Soc. Hort. Sci. 111:869-872.

Bergman, H.F. 1950. Cranberry flower and fruit production in Massachusetts. Cranberries 15:6-10.

Birrenkott, B.A. and E.J. Stang. 1990. Selective flower removal increases cranberry fruit set. HortScience 25:1226-1228.

Birrenkott, B.A., C.A. Henson, and E.J. Stang. 1991. Carbohydrate levels and the development of fruit in cranberry. J. Amer. Soc. Hort. Sci. 116:174-178.

Borras, R., J.L. Tadeo, and E. Primo Millo. 1984. Seasonal carbohydrate changes in two sweet orange varieties of the navel group. Scienta Hort. 24:143-149.

Dana, M.N. 1990. Cranberry management, p. 334-362. In: G.J. Galetta and D.G. Himelrick (eds.). Small fruit crop management. Prentice-Hall, Englewood Cliffs, N.J.

Eaton, G.W. and T.R. Kyte. 1978. Yield component analysis in the cranberry. J. Amer. Soc. Hort. Sci. 103:578-583.

Eck, P. 1990. The American cranberry. Rutgers Univ. Press, New Brunswick, N.Jy.

Fonda, R.W. and L.C. Bliss. 1966. Annual carbohydrate cycle of alpine plants on Mt. Washington, New Hampshire. Bul. Torrey Bot. Club 93:263-277.

Hagidimitriou, M. 1993. Carbohydrate partitioning and photosynthesis in cranberry (Vaccinium macrocarpon Ait.). PhD diss. Univ. of Wisconsin, Madison.

Hawker, G.M. and E.J. Stang. 1985. Characterizing vegetative growth and fruit development in cranberry (Vaccinium macrocarpon Ait) by thermal summation. Acta Hort. 165:311-324.

Karlsson, P.S. 1985. Patterns of carbon allocation above ground in a deciduous (Vaccinium uliginosum) and an evergreen (Vaccinium vitisidaea) dwarf shrub. Physiol. Plant. 63:1-7.

Little, C.H.A. 1970. Derivation of the spring time starch increase in balsam fir (Abies balsamea). Can. J. Bot. 48:1995-1999.

Marucci, P.E. 1966. Cranberry pollination. Cranberries 30:11-13.

McBee, G.G. and N.O. Maness. 1983. Determination of sucrose, glucose and fructose in plant tissue by high performance liquid chromatography. J. Chromatography 264:474-478.

Roper, T.R., E.J. Stang, and G.M. Hawker. 1992. Early season leaf removal reduces fruit set and size in cranberry (Vaccinium macrocarpon Ait). HortScience 27:75.

SAS Institute. 1987. SAS-STAT guide for personal computers, 6th ed. SAS Institute, Cary, N.C.

Sieckmann, S. and A.A. Boe. 1978. Low temperature increases reducing and total sugar concentrations in leaves of boxwood (Buxus sempervirens $\mathrm{L}$.) and cranberry (Vaccinium macrocarpon Ait.). HortScience 13:439-440.

Stewart, W.S. and P. Bannister. 1973. Seasonal changes in carbohydrate content of three Vaccinium spp. with particular reference to Vaccinium uliginosum L. and its distribution in the British Isles. Flora (Jena) 162:134-155. 